\title{
Assessment of Limestone of Ibrahim Formation in Zurbatiya Area, Eastern Iraq for Ordinary Portland Cement Industry
}

\author{
Narjis A. Al-Ali \\ Department of Geology \\ Sattar J. Al-Khafaji \\ College of Science \\ University of Basrah
}

(Received 14/4/2020 , Accepted 27/6/2020)

\begin{abstract}
Limestone deposits of Ibrahim Formation in Zurbatiya area, eastern Iraq are assessed as raw materials for the industry of Ordinary Portland Cement (OPC). The deposits are widely exposed in the area close to Iraq-Iran borders. Six samples were collected from selected section of Ibrahim Formation, which consists of a succession of well-bedded white to gray limestone interbedded with gray marl and marly limestone. $\mathrm{X}$-ray diffraction results show that calcite is the dominant mineral followed by quartz and traces of dolomite which appear in limited samples. X-ray fluorescence results revealed a noticeable increase of $\mathrm{SiO}_{2}$, which might be due to the effect of limestone by silicification process, so the rocks are considered to be a siliceous limestone. The other oxides $\left(\mathrm{CaO}, \mathrm{Al}_{2} \mathrm{O}_{3}, \mathrm{Fe}_{2} \mathrm{O}_{3}, \mathrm{MgO}, \mathrm{Na}_{2} \mathrm{O}, \mathrm{K}_{2} \mathrm{O}, \mathrm{TiO}_{2}, \mathrm{SO}_{3}\right.$, and $\left.\mathrm{P}_{2} \mathrm{O}_{5}\right)$ are within the acceptable limits required for cement industry. Cement chemical parameters indicated that there is a decrease in the lime saturation factor (LSF) and an increase in silica ratio (SR) in comparison with the chemical parameters listed by standard specifications due to the increase of silica content. This increase can be adjusted by adding clays, or any other source of low silica content in addition to use iron and alumina as correcting additive materials for the cement mixture.
\end{abstract}

Key words: OPC, Ibrahim Formation, Zurbatiya, Siliceous limestone, LSF.

$$
\begin{aligned}
& \text { تقييم الصخور الجيرية لتكوين ابراهيم في منطقة زرباطية شرقي العراق لصناعة الاسمنت } \\
& \text { البورتلاندي الاعتيادي }
\end{aligned}
$$

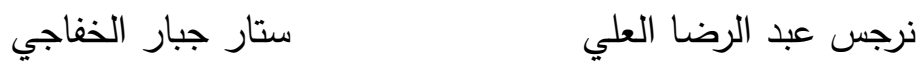

$$
\begin{aligned}
& \text { قسم علم الأرض } \\
& \text { كلية العلوم } \\
& \text { جامعة البصرة } \\
& \text { المستخلص }
\end{aligned}
$$




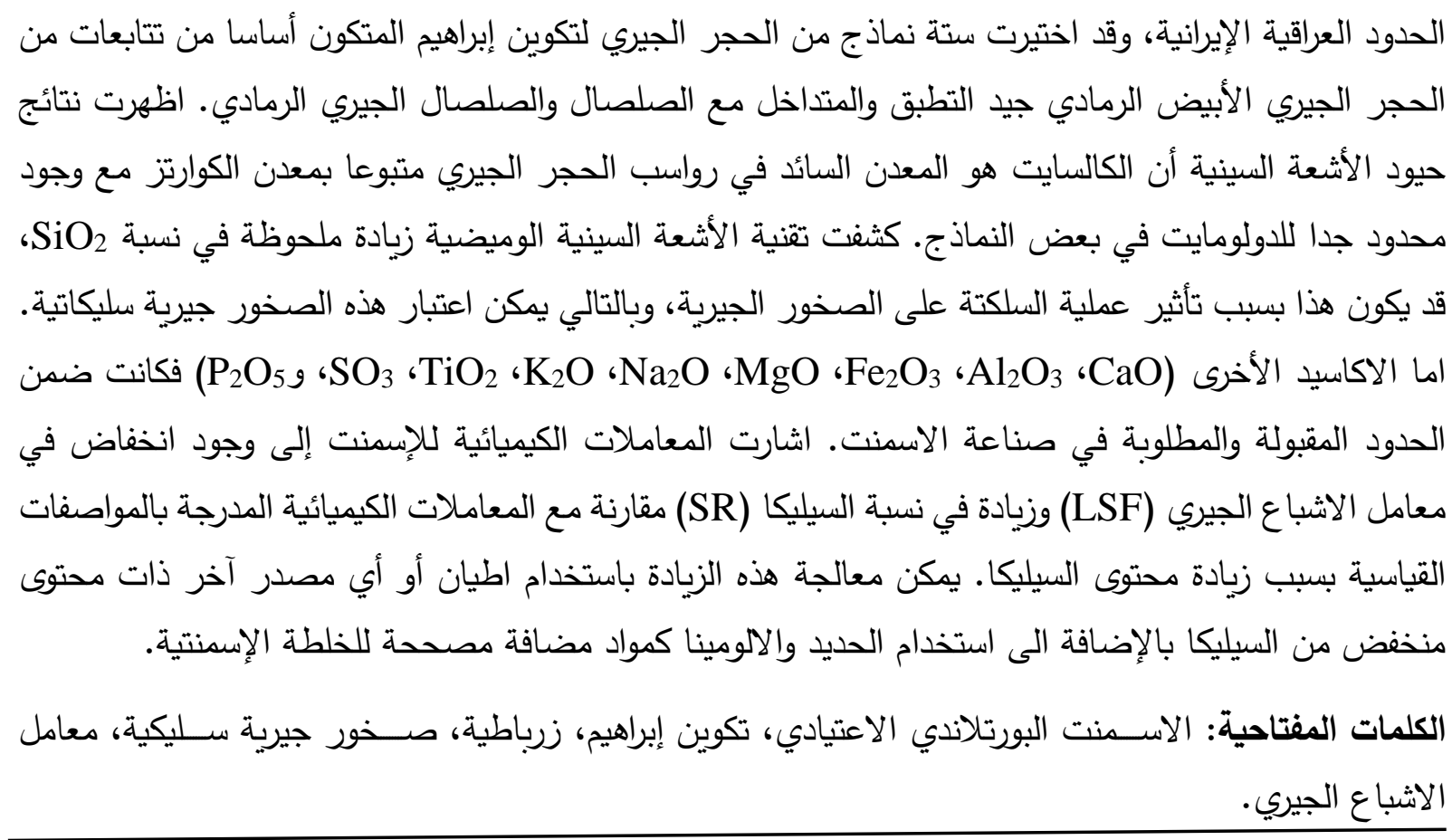

\section{INTRODUCTION}

The cement industry is one of the most pillars of economic development and one of the most important manufacturing industries (John, 2020) because cement is the main binding material for the construction industries (Ali, 2014). Iraq is one of the old manufacturers of cement, due to the abundance of raw materials and the availability of technology for manufacture (Mohammed et al., 2013). The demand for cement is increasing due to the urban development witnessed in the country especially after the campaigns of the reconstruction of infrastructure and expansion in the construction of housing units and service and productive institutions (Al-Obaidy, 2010). Therefore, there was need to explore other resources of limestone as raw materials.

Limestone raw material is considered as the lifeline for any cement industry and cement plant because it is the main raw material component (Rao et al., 2011). The mineralogical studies are very necessary for diagnosis of the digenesis processes in limestone, as well as to distinguish the type and quality of minerals accompanied with limestone (Yezdeen, 1990). The low concentrations of alkali and sulfate in raw materials led to a low-alkali production cement that is the favored cement in all cement manufactures (Ismail, 2016), so the assessment must be done for raw materials, especially limestone and clay because successful clinker production demands, as known, a mixture of limestone, clay, and corrective additives as well as a correct calculation of clinker mixture (Mirza and Fatah, 2018)

The limestone deposits of Ibrahim Formation have a good extension and thickness that can be exploited in several fields by open pit mining. The present study aims to conduct mineralogical and chemical studies of Ibrahim limestone deposits in Zurbatyia area using XRD and XRF techniques to assess their suitability as raw materials for industry of Ordinary Portland Cement (OPC). 


\section{GEOLOGY AND LOCATION OF THE STUDY AREA}

The study area is located in Zurbatiya area at about $80 \mathrm{~km}$ east of Wasit Governorate (Figure 1). The study area represents the extreme margin of the low folded zone located between High Mountain and Mesopotamian plain provinces of Iraq (Yacoub et al., 2012 in Al-Shwaily and Al-Obaidi, 2019). There is a good exposed succession of Oligocene-Miocene formations in the study area represented by the following:

1-Ibrahim Formation: The present study focuses on its limestone beds, where it consists of a good succession of white to gray well-bedded limestone interbedded with gray marl and marly limestone (Figure 2). The underline formation is not exposed in the study area; the overlying formation is Serikagni and sometimes overlain by Dhiban Formation (Figure 3). The exposed thickness of Ibrahim Formation is more than $20 \mathrm{~m}$ (Figure 4).

2-Serikagni Formation: The formation is composed of a succession of gray to white marl to marly limestone and limestone and overlain by Dhiban Formation.

3-Dhiban Formation: The formation comprises massive gypsum, thin beds of marl and brecciated recrystallized limestone. The formation is underline by Serikagni Formation and overlain by the Jeribe Formation in the study area.

4-Jeribe Formation: The formation is composed of limestone and dolomitic limestone. The upper contact of Jeribe Formation is unconformable with Fatha Formation as seen in study area.

5-Fatha Formation: The formation is well exposed and characterized by cyclicity nature and composed of alternations of gypsum, marl and red claystone. It is overlain by Injana Formation and underline by Jeribe Formation.

6-Injana Formation: The formation is composed of alternations of brown sandstone interbedded with brown claystone, and siltstone. The sandstone becomes thicker, less compacted and coarsening upwards. The formation is overlain by Mukdadiya Formation. 


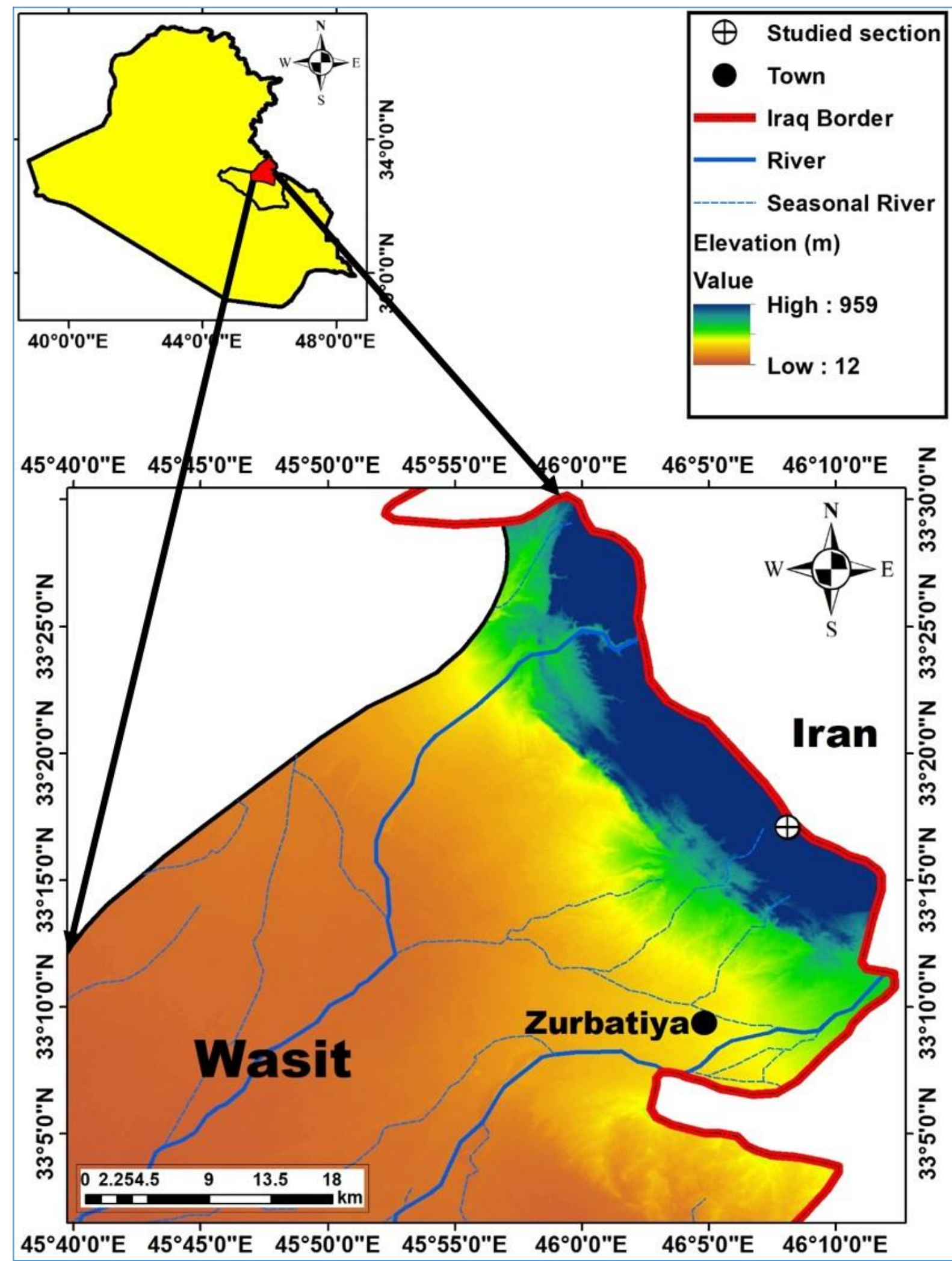

Figure 1: The location map of the study area (Prepared by the authers). 
23 Assessment of Limestone of Ibrahim Formation in Zurbatiya Area, Eastern Iraq ......

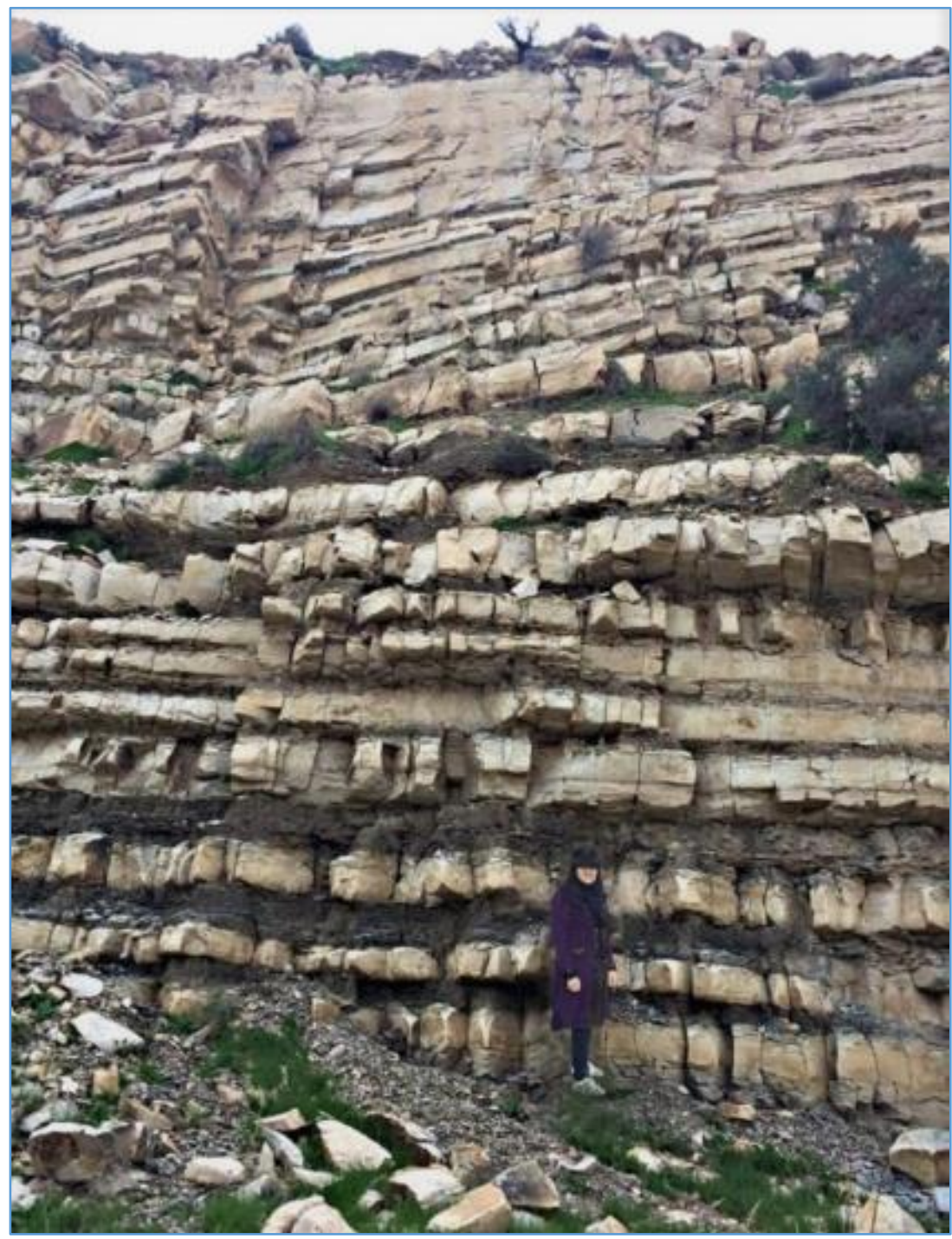

Figure 2: Ibrahim Formation at Zurbatyia area.

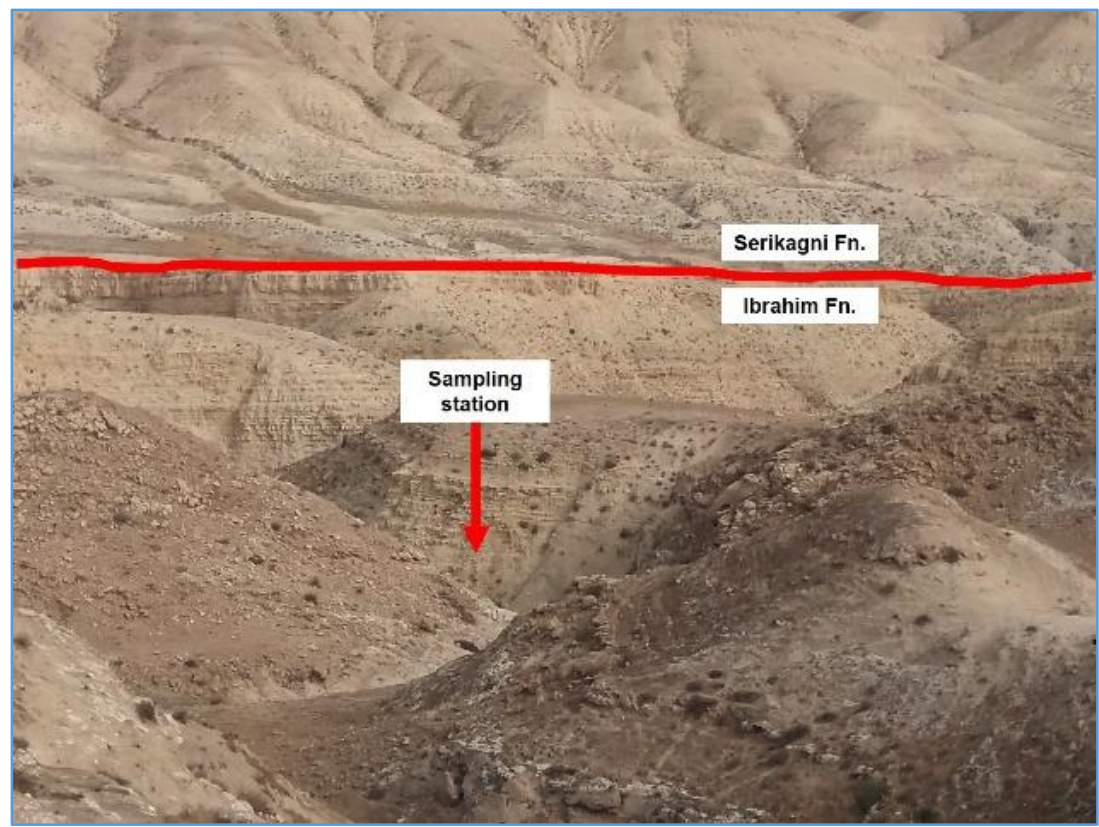

Figure 3: Ibrahim limestone Formation in study area. 


\begin{tabular}{|c|c|c|c|c|c|c|c|c|c|}
\hline \multirow{40}{*}{$\begin{array}{c}\text { Ibrahim } \\
\text { Fn. }\end{array}$} & \multirow{2}{*}{42} & \multirow{2}{*}{ (s6) } & \multirow{2}{*}{ 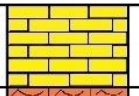 } & \multirow{2}{*}{ Gray to white limestone } & \multirow{3}{*}{$\begin{array}{c}\text { Formatior } \\
\text { (Fn.) } \\
\begin{array}{c}\text { Serikagni } \\
\text { Fn. }\end{array} \\
\end{array}$} & $\begin{array}{c}\begin{array}{c}\text { Thickness } \\
(\mathrm{cm})\end{array} \\
\end{array}$ & \multirow[t]{2}{*}{ Sample } & \multirow[t]{2}{*}{$\begin{array}{l}\text { Lithologic } \\
\text { column }\end{array}$} & \multirow{2}{*}{$\begin{array}{l}\text { Lithologic description } \\
\text { Gray to white marl to marly limestone }\end{array}$} \\
\hline & & & & & & \multirow[t]{2}{*}{$?$} & & & \\
\hline & 18 & & & Gray to black marly limestone & & & & mathent & \\
\hline & \multirow{2}{*}{49} & & \multirow{2}{*}{ 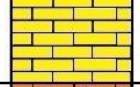 } & \multirow[t]{2}{*}{ Gray to white limestone } & & 35 & (s10) & 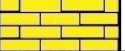 & Gray to white limestone \\
\hline & & & & & & \multirow{3}{*}{56} & & 11 & \multirow{3}{*}{ Gray to white limestone } \\
\hline & 22 & & 然 & Gray to black marly limestone & & & & 54 & \\
\hline & \multirow{2}{*}{52} & \multirow{2}{*}{\multicolumn{2}{|c|}{$\begin{array}{|llll|} & & & \\
1 & & \\
1 & & \\
& & & \\
\end{array}$}} & \multirow[t]{2}{*}{ Gray to white limestone } & & & & $\begin{array}{ll}1 \\
\end{array}$ & \\
\hline & & & & & & \multirow{3}{*}{51} & & $\mathrm{P}_{1} 1 \mathrm{~L}$ & \\
\hline & 20 & & M目A & Gray to black marly limestone & & & & (1) & Gray to white limestone \\
\hline & 36 & \multicolumn{2}{|r|}{\begin{tabular}{|llll} 
& & \\
1 & & \\
\end{tabular}} & Gray to white limestone & & & & 1914 & Gray to black marly limestone= \\
\hline & 20 & & A & Gray to black marly limestone & & & & | & Rocky oran toubite limesto \\
\hline & 37 & S5 & \begin{tabular}{|l}
1 \\
1
\end{tabular} & Gray to white limestone & & 05 & & 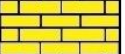 & - \\
\hline & 21 & & $M$ & Gray to black marly limestone & & 8 & & $\begin{array}{ll}1 \\
2\end{array}$ & Gray to black marly limestone- \\
\hline & 58 & & $\begin{array}{|llll|}1 & & \\
1 & & \\
\end{array}$ & White to gray blocky limestone & & 39 & (s9) & (1, 1 & Blocky gray to white limestone \\
\hline & & & ג & & & 9 & & 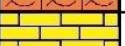 & Gray to black marly limestone. \\
\hline & 23 & & & Gray to black marly limestone & & 50 & & $\begin{array}{lll}1 & 1 \\
& 1 \\
\end{array}$ & Blocky gray to white limestone \\
\hline & & & $\begin{array}{lll}1 & 1 \\
& 1 & 1 \\
\end{array}$ & & & 16 & & 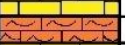 & Gray to black marly limestone \\
\hline & & & 年 & (2) & $\begin{array}{c}\text { Ibrahim } \\
\text { Fn. }\end{array}$ & 56 & & $\begin{array}{lll}1 & 1 \\
& 1 & 1 \\
\end{array}$ & Blocky gray to white limestone \\
\hline & 34 & & & Gray to black marly IImestone & & & & $\begin{array}{lll} & 1 \\
& 1 \\
\end{array}$ & \\
\hline & & & & & & 11 & & जर्ति & Gray to black marly limestone \\
\hline & 64 & & \begin{tabular}{|lll} 
& & \\
1 & & \\
1 & 1 \\
1 &
\end{tabular} & White to gray blocky limestone & & 58 & & \begin{tabular}{|l} 
\\
1 \\
1
\end{tabular} & Blocky gray to white limestone \\
\hline & & & & & & 26 & & 01 & Gray to black marly limestone \\
\hline & 20 & & & Gray to black marly limestone & & & & (1, & \\
\hline & 65 & (s4 & 年 & White to gray blocky limestone & & 56 & & \begin{tabular}{|lll} 
& & \\
1 & 1 & \\
1 & 1 & 1 \\
\end{tabular} & fructures with iron oxides staining \\
\hline & & & +1 & & & 20 & & थㅜㄱ & Gray to black marly limestone \\
\hline & 50 & & & Gray to black marly limestone & & 64 & s8 & 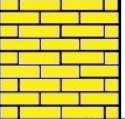 & $\begin{array}{l}\text { Gray to white blocky limestone, highly } \\
\text { fructures with iron oxides staining }\end{array}$ \\
\hline & & & (1, & & & 17 & & 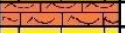 & Gray to black marly limestone \\
\hline & 60 & & 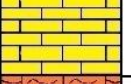 & 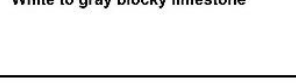 & & 55 & & 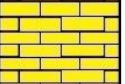 & $\begin{array}{l}\text { Gray to white blocky limestone, highly } \\
\text { fructures with iron oxides staining }\end{array}$ \\
\hline & 56 & & & Gray to black marly limestone & & 18 & & ands & Gray to black marly limestone \\
\hline & & & 11 & & & 52 & & $\begin{array}{|llll|} & & \\
& & \\
\end{array}$ & $\begin{array}{l}\text { Gray to white blocky limestone, highly } \\
\text { fructures with iron oxides staining }\end{array}$ \\
\hline & & & | & & & & & \begin{tabular}{|lll}
1 & 1 \\
& 1 & 1 \\
\end{tabular} & \\
\hline & 63 & & لـ, & White to gray blocky limestone & & 15 & & $-1,4$ & Gray to black marly limestone \\
\hline & & & $\begin{array}{ll}1 \\
1\end{array}$ & & & 54 & & $\begin{array}{ll}1 & 1 \\
& 1 \\
\end{array}$ & $\begin{array}{l}\text { Gray to white blocky limestone, highly } \\
\text { fructures with iron oxides staining }\end{array}$ \\
\hline & & & & & & & & $1 \quad 1,1$ & \\
\hline & 59 & & txit & Gray to black marly limestone & & 20 & & $\mathrm{NAn}$ & Gray to black marly limestone \\
\hline & & & & & & 49 & S7 & 1, 1,1 & Gray to white limestone \\
\hline & & & \begin{tabular}{|l|l|l|l|l|} 
& 1 & \\
\end{tabular} & & & & & 1, 1 & \\
\hline & or & (S3) & 1, & White to gray blocky limestone & & 26 & & 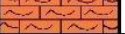 & Gray to black marly limestone \\
\hline & & & (1) & & & & & 1,14 & \\
\hline & $?$ & & It & Gray to black marly limestone & & 54 & & $\begin{array}{llllll} & 1 & 1 & \\
\end{array}$ & Gray to whlte llimestone \\
\hline & & & & Leg & & & & & \\
\hline & & & & & & 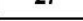 & & & Gray to black marly limestone \\
\hline 0 & 50 & $1008>2>>$ & & Lintestome & & & & (1) & \\
\hline & & & & Marly limestone & & & & 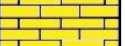 & Gray to white limestone \\
\hline & & & & Analysis samples & & 34 & & An & Gray to black marly limestone \\
\hline
\end{tabular}

Figure 4: Stratigraphic columnar section of the Ibrahim Formation at Zurbatiya area. 


\section{METHODOLOGY}

\section{Sampling:}

The fieldwork was carried out in Zurbatiya area, near Badra city in Wasit Governorate, eastern Iraq. The objectives of the fieldwork are to describe the geology of the study area, and to collect limestone samples from a section of good exposures of wide thickness and lateral extension (Figure 2). Eight samples were collected from Ibrahim Formation in the study area located at N $33^{\circ} 16^{\prime} 12^{\prime \prime}$ and E $46^{\circ} 08^{\prime} 42^{\prime \prime}$ (Table $1)$; then, the samples were stored in nylon bags and subjected to cleaning, crushing, grinding, and sieving so as to be ready for various mineralogical (XRD) and chemical (XRF) analysis.

Table 1: The location, thickness, and number of samples of Ibrahim Formation in the study area.

\begin{tabular}{|c|c|c|c|c|}
\hline Formation & Coordinates & Lithology & Number of samples & Thickness \\
\hline Ibrahim & $\begin{array}{l}\text { N } 33^{\circ} 16^{\prime} 12^{\prime \prime} \\
\text { E } 46^{\circ} 08^{\prime} 42^{\prime \prime}\end{array}$ & Limestone, and marl to marly limestone & 8 & $>20 \mathrm{~m}$ \\
\hline
\end{tabular}

\section{Mineralogical analysis:}

X-ray diffraction method (XRD) is the most widely method because it is a nondestructive method of mineral structure, and it is characterized by its speed and accuracy in the analysis (Lavina et al., 2014). Six samples of limestone were selected to conduct an XRD analysis and scanned at $(2 \theta)$ range from $\left(5^{\circ}-65^{\circ}\right)$. In addition to two samples selected to separate the insoluble residues from limestone according to Lumsden, (1974) method to detect the mineralogy of insoluble residues. The XRD instrument used is Broker D2 phaser in the Iraqi German laboratory, University of Baghdad, College of Science, Geology Department.

\section{Chemical Analysis:}

Chemical analysis is considered as the basis at which the cement industry depends on. X-ray fluorescence (XRF) is a common technique for geological samples, it is considered as a non-destructive, environmentally friendly and fast analysis method with high accuracy are reproducibility (Abdunnabi, 2012). Limestone samples were taken with a weight of $200 \mathrm{~g}$ after crushing and grinding by using agate mortar, and then sieved to $70 \mu \mathrm{m}$. Six limestone samples were analyzed for their major oxides contents by using XRF techniques (XRF: Ed-XRF Instrument Spectro-Xepos of Ametek Company in the Iraqi German Laboratory in the University of Baghdad, College of Science, Department of Geology).

\section{Cement Chemical Parameters:}

Many chemical parameters are calculated to evaluate the chemical composition of raw materials and to design the raw mix materials. It is possible to predict a good proportion of raw mix and other corrected materials that must be added to meet the requirement of the local and international standard for cement raw materials. In the present study, only one component of the mixture, which is limestone, was studied. However, these parameters were calculated to take into consideration the specifications of the clays that complement the mixture. In order to contribute to the modification of 
the values of these parameters within the permissible limits within the specifications of the cement mixture. Therefore, these parameters must be recalculated to assess the suitability of the components of the mixture after studying the second main component represented by clays.

1-Lime Saturation Factor (LSF): The LSF is the most critical control ratio that is used to measure the degree of conversion of silica, alumina, and iron oxide to their basic calcium compounds (Hewlett and Liska, 2019). According to Hewlett (2006), LSF can be determined by the equation:

$$
\mathrm{LSF}=\frac{\mathrm{CaO} \%}{2.8\left(\mathrm{SiO}_{2} \%\right)+1.2\left(\mathrm{Al}_{2} \mathrm{O}_{3} \%\right)+0.65\left(\mathrm{Fe}_{2} \mathrm{O}_{3} \%\right)} \quad \times 100
$$

2-Silica Ratio (SR): It is the ratio of the silica oxide to the summation of aluminum and iron oxides (Peray, 1986), given as:

$$
\mathrm{SR}=\quad \begin{array}{ll}
\mathrm{SiO}_{2} \% \\
\mathrm{Al}_{2} \mathrm{O}_{3} \%+\mathrm{Fe}_{2} \mathrm{O}_{3} \%
\end{array}
$$

3- Alumina Ratio (AR): $A R$ is used to calculate the ratio of $\mathrm{Al}_{2} \mathrm{O}_{3}$ to $\mathrm{Fe}_{2} \mathrm{O}_{3}$ in the raw mix materials (Duda, 1985). According to Hewlett and Liska (2019), the alumina ratio is defined as:

$$
\mathrm{AR}=\quad \begin{aligned}
& \mathrm{Al}_{2} \mathrm{O}_{3} \% \\
& \mathrm{Fe}_{2} \mathrm{O}_{3} \%
\end{aligned}
$$

\section{RESULTS AND DISCUSSION}

\section{Mineralogical analysis:}

The results of the mineralogical analysis showed that calcite is the main mineral in all the limestone samples, and is present in good percentages with an average of $78.13 \%$. The highest percent of calcite $84.8 \%$ represents the samples at the top and bottom of the section (Figure 5), while the lowest percent $72.2 \%$ is at the middle part of section (Figure 6 ). The excess of quartz in limestone may be due to silcification process. The maximum percentage of quartz is found at the top of section $(18.5 \%$ ) (Figure 7), whereas the minimum value is at the bottom (11.4\%) (Figure 8), so it is considered that limestone as siliceous limestone type. There is limited amount of dolomite in some limestone samples with an average of $7.53 \%$. The limited presence of dolomite leads to a low $\mathrm{MgO}$ content (1.95-3.37, Table 2) in all the limestone samples indicating a good raw material for the manufacture of cement. 
27 Assessment of Limestone of Ibrahim Formation in Zurbatiya Area, Eastern Iraq ......

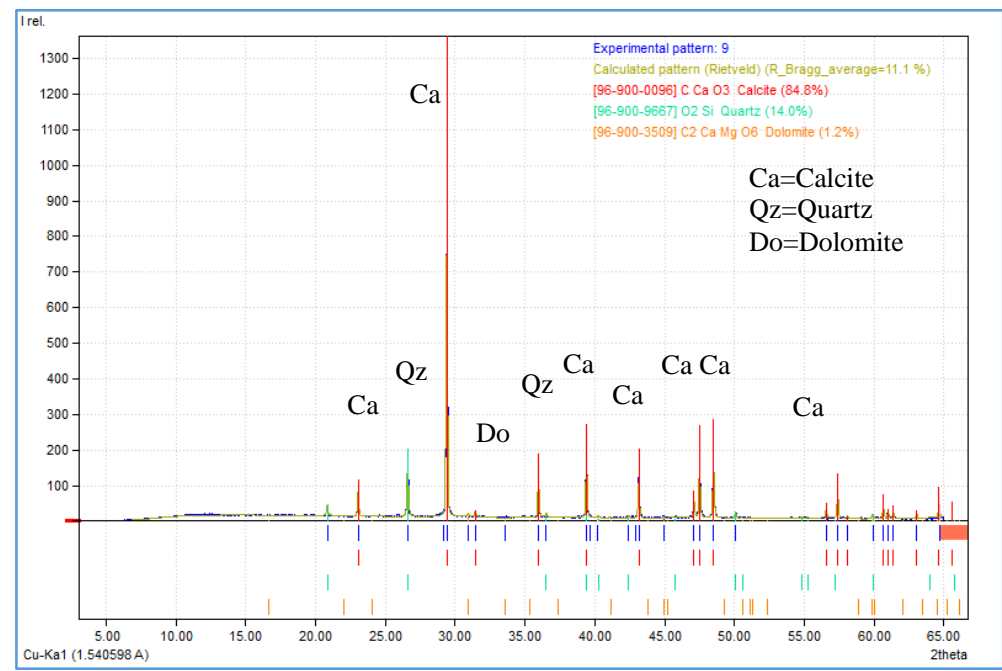

Figure 5: XRD patterns of limestone (S9).

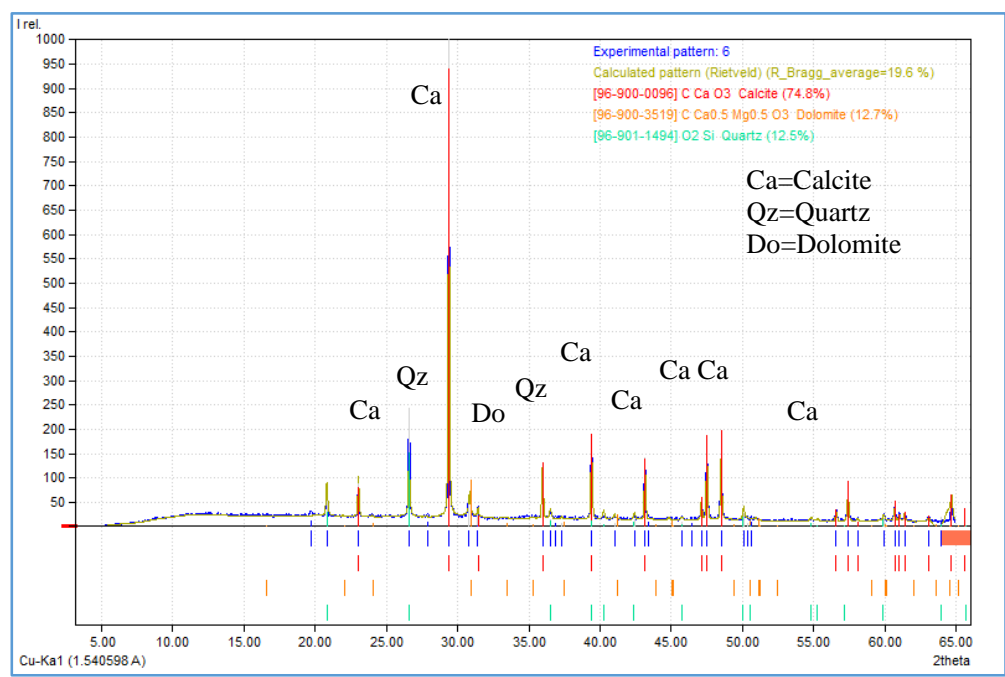

Figure 6: XRD patterns of limestone (S6).

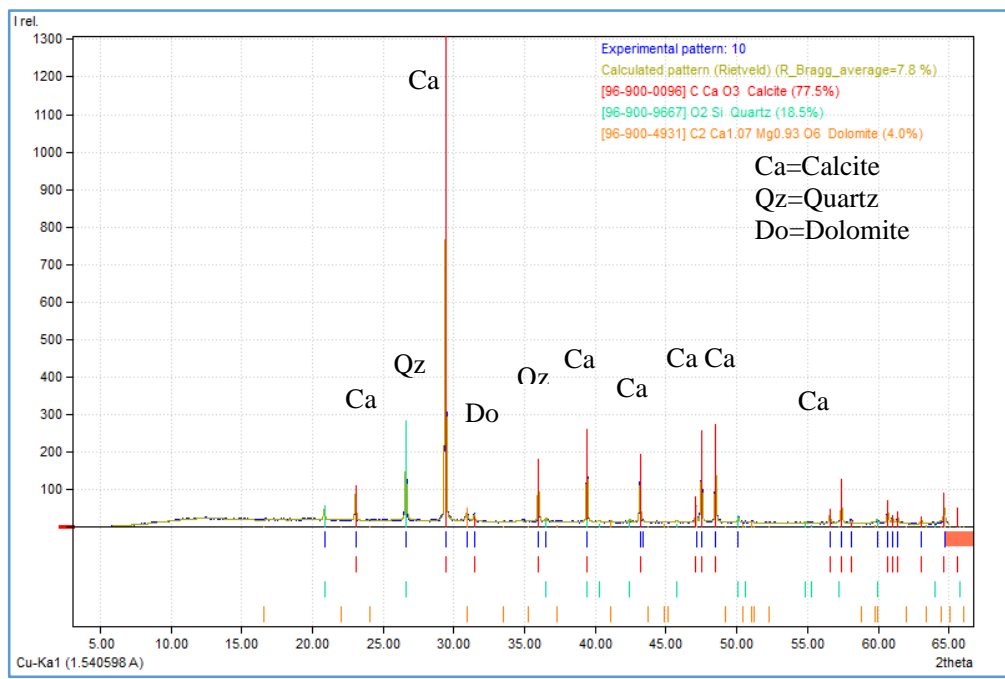

Figure 7: XRD patterns of limestone (S10). 


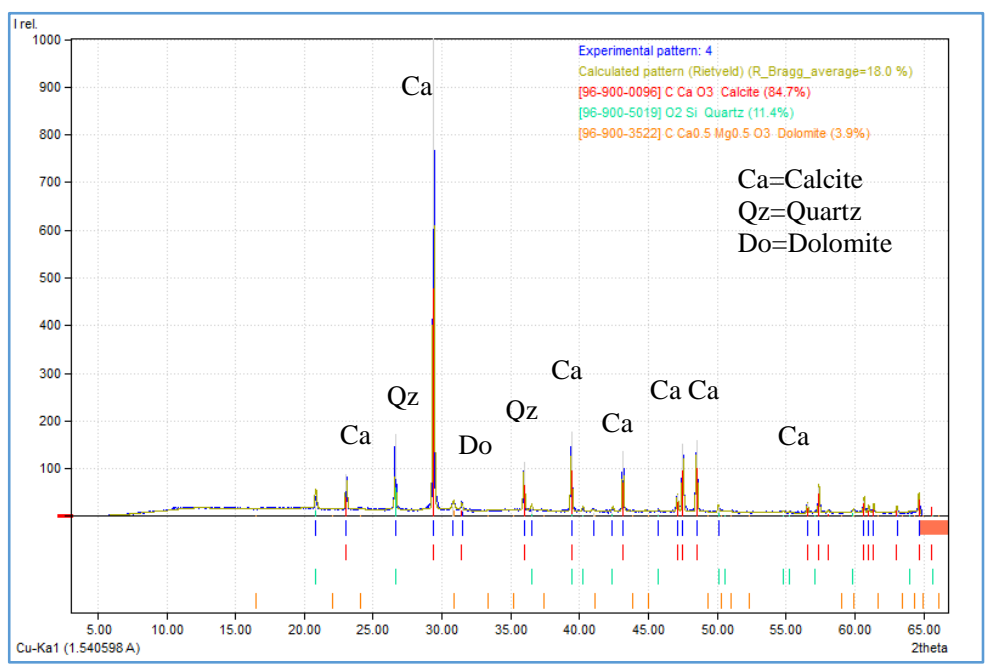

Figure 8: XRD patterns of limestone (S4).

\section{Insoluble Residue:}

Insoluble residue are materials and minerals which do not dissolve in hydrochloric acid, and generally composed of quartz and clay minerals (Bhattacharyya, 2017). The results show that IR values range from $19.83 \%$ to $24.83 \%$. Quartz is the main mineral (as impurity) in limestone samples (Figure 9 and 10) having a range from 91.8-95.8.

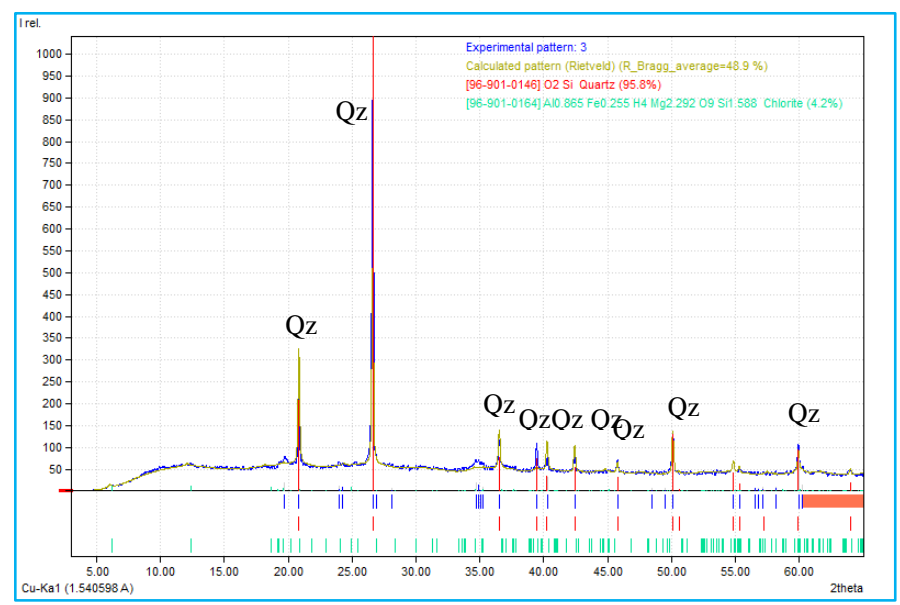

Figure 9: XRD patterns of insoluble residue of limestone, sample (S3).

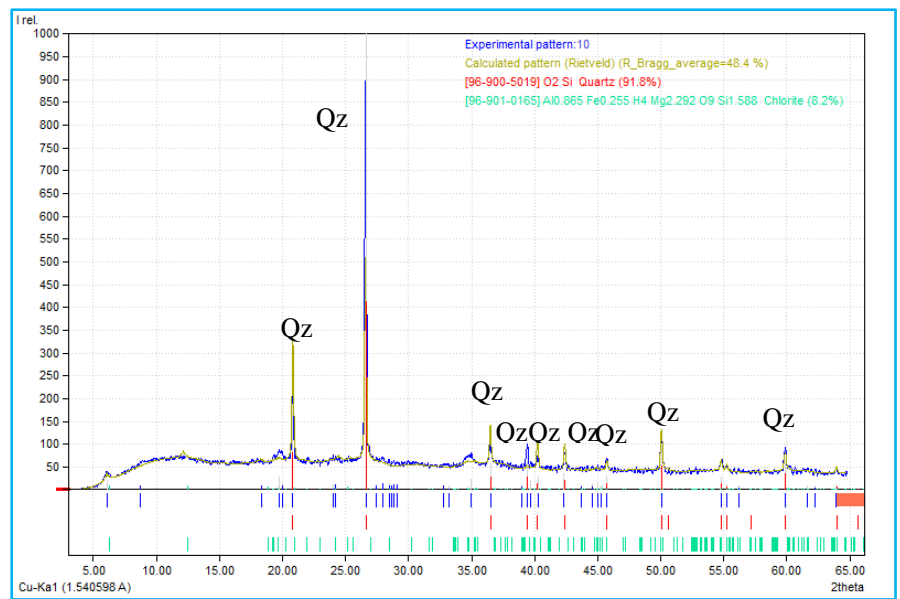

Figure 10: XRD patterns of insoluble residue of limestone, sample (S10). 


\section{Chemical Analysis:}

The chemical analysis of limestone showed that $\mathrm{CaO}$ is the dominant oxide having a range from $45.79 \%$ to $52.11 \%$ with an average of $48.99 \% . \mathrm{SiO}_{2}$ ranges from $10.76 \%$ to $17.96 \%$ with an average of $14.38 \% . \mathrm{Al}_{2} \mathrm{O}_{3}$ ranges from $1.55 \%$ to $2.87 \%$ with an average of $2.24 \%$. $\mathrm{Fe}_{2} \mathrm{O}_{3}$ ranges from $1.2 \%$ to $2.11 \%$ with an average of $1.66 \%$. $\mathrm{MgO}$ ranges from $1.95 \%$ to $3.37 \%$ with an average of $2.71 \%$. The low value of $\mathrm{MgO}$ is due to less effect of the dolomitization process, where the dolomite mineral $\mathrm{CaMg}\left(\mathrm{CO}_{3}\right)_{2}$ is the main source of $\mathrm{MgO}$. The limestone becomes more suitable for the manufacture of cement when the percent of $\mathrm{MgO}$ does not exceed 5\% according to IQS No.5 (1984), $6 \%$ according to ASTM C150-85 (1986) and 4\% according to BS12 (1989). Limestones have low content of sulfate with an average of $0.20 \%$. IQS No.5 (1984) sets that the percent of sulfate in OPC is $2.5 \%$ max, $3 \%$ max according to BS12 (1989), ASTM C15085 (1986). Alkalis content $\left(\mathrm{Na}_{2} \mathrm{O}\right.$ and $\left.\mathrm{K}_{2} \mathrm{O}\right)$ is also low with an average of $1.12 \%$. Alkalis react with silica to produce an increase in volume causing damage of concrete (Schafer, 1987), so ASTM C150-85 (1986) sets that the cement should contain no more than $1.6 \%$ alkalis. All these oxides percentages in present study are within the acceptable ranges of the raw materials for the cement industry (Table 2), on the other hand, their higher percent have a negative impact on the operations of the kiln as well as the impact on the quality of cement (Al-Ali et al., 2008).

Table 2: Chemical analysis of limestone samples.

\begin{tabular}{|c|c|c|c|c|c|c|c|c|c|c|c|c|}
\hline Sample & $\mathbf{S i O}_{\mathbf{2}}$ & $\mathbf{A l}_{2} \mathbf{O}_{\mathbf{3}}$ & $\mathbf{F e}_{2} \mathbf{O}_{\mathbf{3}}$ & $\mathbf{N a}_{\mathbf{2}} \mathbf{O}$ & $\mathbf{K}_{\mathbf{2}} \mathbf{O}$ & $\mathbf{T i O}_{\mathbf{2}}$ & $\mathbf{C a O}$ & $\mathbf{M g O}$ & $\mathbf{S O}_{\mathbf{3}}$ & $\mathbf{P}_{\mathbf{2}} \mathbf{O}_{\mathbf{5}}$ & $\mathbf{L . O . I}$ & Total \\
\hline S3 & 12.40 & 1.89 & 1.49 & 0.66 & 0.42 & 0.37 & 52.11 & 2.67 & 0.28 & 0.08 & 33.10 & 105.48 \\
\hline S4 & 10.76 & 1.55 & 1.28 & 0.71 & 0.37 & 0.34 & 50.37 & 2.21 & 0.15 & 0.08 & 33.40 & 101.22 \\
\hline S6 & 16.84 & 2.77 & 2.11 & 0.60 & 0.59 & 0.48 & 45.79 & 3.17 & 0.24 & 0.09 & 30.80 & 103.48 \\
\hline S7 & 17.96 & 2.87 & 2.05 & 0.62 & 0.60 & 0.48 & 46.13 & 3.37 & 0.23 & 0.09 & 31.30 & 105.71 \\
\hline S9 & 12.68 & 1.60 & 1.20 & 0.61 & 0.37 & 0.36 & 49.86 & 1.95 & 0.15 & 0.12 & 34.90 & 103.79 \\
\hline S10 & 15.65 & 2.75 & 1.86 & 0.56 & 0.60 & 0.45 & 49.69 & 2.92 & 0.13 & 0.11 & 30.60 & 105.30 \\
\hline Min. & 10.76 & 1.55 & 1.20 & 0.56 & 0.37 & 0.34 & 45.79 & 1.95 & 0.13 & 0.08 & 30.60 & 101.22 \\
\hline Max. & 17.96 & 2.87 & 2.11 & 0.71 & 0.60 & 0.48 & 52.11 & 3.37 & 0.28 & 0.12 & 34.90 & 105.71 \\
\hline Avg. & 14.38 & 2.24 & 1.66 & 0.63 & 0.49 & 0.41 & 48.99 & 2.71 & 0.20 & 0.10 & 32.35 & 104.16 \\
\hline
\end{tabular}

\section{Cement chemical parameters}

Cement chemical parameters showed that LSF range of limestone was from 83.78 to 153.48 with an average of 116.04 (Table 3 ). The preferable range of LSF of cement raw mixture is 92-96 (Chatterjee, 1983). On the other hand, according to Newman and Choo (2003), LSF of typical clinker is 95-97. The increase in the value of LSF means increasing the percentage of free lime in clinker, which negatively affects the quality of cement due to its high potential to hydration and thus the expansion and swelling, resulting in stresses, cracks and fractures in concrete (Taylor, 1977). In addition, a higher value of LSF makes the mixture difficult to burn (Rao et al., 2011). SR range of limestone was from 3.40 to 4.54 with an average of 3.75. The range of SR for the raw mix materials is between 1.8 and 3.2, but the perfect value is between 2.2 and 2.6 (Duda, 1985). According to Newman and Choo (2003), SR of typical clinker is 2.4-2.6. The increases in the value of this parameter lead to a decrease in the ability to burn the raw mix and need high temperatures (Mirza and Fatah, 2018); it also causes a decrease in liquid phase content (Duvallet, 2014). When the value of this parameter is low, the amount of liquid phase will increase, improving the burn ability of the raw mix (Rao et al., 2011). AR range of limestone was from 1.21 to 1.48 with an average of 1.33 (Table 
3). The good values of this ratio between of 1.3-2.8, but the value between of 1.4-1.6 is the desirable range (Peray, 1986). According to Newman and Choo (2003), AR of typical clinker is 1.5-1.8. AR equal to 1.4 will be easier to burn; there is more clinker liquid at a lower temperature (Rao et al., 2011). AR only has an effect on clinker formation at low temperature and affects the color of cement (Mirza and Fatah, 2018). Cement chemical parameters indicated that there is a decrease in the lime saturation factor and an increase in silica ratio due to the increase in silica content. The increase in the percentage of silica can be addressed by using clays or any other source with low silica content, in addition to the use of iron, alumina and other additives as correcting materials for the cement mixture. There is a decrease in AR of limestone where can be addressed by adding $\mathrm{Al}_{2} \mathrm{O}_{3}$ source as a correcting material such as Bauxite.

Table 3: Calculated LSF, SR and AR for limestone samples.

\begin{tabular}{|c|c|c|c|}
\hline Sample No. & LSF & SR & AR \\
\hline S3 & 137.31 & 3.67 & 1.27 \\
\hline S4 & 153.48 & 3.80 & 1.21 \\
\hline S6 & 88.32 & 3.45 & 1.31 \\
\hline S7 & 83.78 & 3.65 & 1.40 \\
\hline S10 & 130.53 & 4.54 & 1.34 \\
\hline Max. & 102.83 & 3.40 & 1.48 \\
\hline Min. & 153.48 & 4.54 & 1.48 \\
\hline Avg. & 83.78 & 3.40 & 1.21 \\
\hline
\end{tabular}

\section{CONCLUSIONS}

1- Field observations showed that Ibrahim Formation has good extensions and thicknesses of limestone that can be exploited.

2- $\mathrm{CaO}$ is the main component of limestone samples with some excess of $\mathrm{SiO} 2$, so the limestone is considered to be a siliceous limestone type.

3- The excess of silica content in the raw materials is due to silicification, while the traces of dolomite reflect the limit effect of dolomitization. The later leads to a decrease in the $\mathrm{MgO}$ contents in the raw materials, and be good raw materials and suitable for the cement industry.

4- LSF, SR and AR values of the raw materials contend for the need to make some adjustments of raw mix design and can be adjusted by using clays or other sources of low silica content, alumina, and iron as correcting additive materials.

\section{REFERENCES}

Abdunnabi, A. R., 2012. XRF Analysis of Portland Cement for Major and Trace Elements. Eleveth Arab Conference on the Peaceful Uses of Atomic Energy. Khartoum. Sudan, 44(26), 1-15.

Al-Ali, S. H., Al-Khafaji, S. J., and Thanoon, T. A. R., 2008. Chemical and mineralogical assessment of raw materials for cement industry at Kufa cement plants. Basrah journal of science, 26(1), 25-36. (In Arabic). 
Ali, Y. A. D., 2014. Production of a Multi-Purposes Portland Cement. Unpub. MSc. Thesis, Faculty of Engineering and Technology, University of Gazira: 63P. (In Arabic).

Al-Obaidy, S. A. H., 2010. Geological Petrographic and Petrophysical Studies to Evaluate the Stability of Limestone for Cement Industry in the Outcrops of Fath'a Formation, Sukkaria Area, West of Baiji. Iraqi Journal of Science, 15(1), 107-122. (In Arabic).

ASTM, (C150-85), 1986. Standard specification for Portland cement. PP.152-158, In: Annual book of ASTM standards, Vol.04.02.

Bhattacharyya, K., 2017. Insoluble Residue Analysis of Limestone in Kolhan Group: Tectonic Implications. Global J Technol Optim, 7, 209.

BS, 12, 1989. British standard specification for Portland cements. Part 1, 5P.

Chatterjee, T. K., 1983. Burnability and clinkerization of cement raw mixes. In Advances in Cement Technology (pp. 69-113). Pergamon.

Duda, W. H., 1985. Cement-Data-Book. International Process Engineering in the Cement Industry, $3^{\text {rd }}$ edition, Bauverlag, GmbH. Wiesbaden and Berlin Macdonald and Evans, London, 539P.

Duvallet, T. Y. F., 2014. Influence of Ferrite Phase in Alite Calcium Sulfoaluminate Cements. Unpub. PhD. Thesis, College of Engineering, University of Kentucky, $213 \mathrm{P}$.

Hewlett, P. C., 2006. Lea's Chemistry of Cement and Concrete. 4th ed, Elsevier Science and Technology Books. 1066P.

Hewlett, P., and Liska, M., 2019. Lea's chemistry of cement and concrete. $5^{\text {th }}$ edition, Butterworth-Heinemann, 880P.

IQS, No.5, 1984. Portland cement. Number 5. Central Agency for standardization and Quality Control. Ministry of Planning, 10p (In Arabic).

Ismail, N. R. (2016). Evaluation of limestone and marl of Shiranish Formation (cretaceous) for cement industry, Koya area, NE Iraq. International Journal of Engineering Technology, Management and Applied Sciences, 4(3), 44-53.

John, J. P., 2020. Parametric Studies of Cement Production Processes. Journal of Energy, 2020, 1-17.

Lavina, B., Dera, P. and Downs, R.T., 2014. Modern X-ray diffraction methods in mineralogy and geosciences. Reviews in Mineralogy and Geochemistry, 78(1), pp.1-31.

Lumsden, D. N., 1974. Relationships among insurable residue, dolostone and limestone facies. Jour. sed. Petrol., 44, 450-455.

Mirza, T. A., and Fatah, C. M., 2018. Evaluating the Suitability of Avroman Limestone, Halabja Governorate for Cement Industry. Iraqi Bulletin of Geology and Mining, 14(1), 103-120. 
Mohammed, I. A., Akaib, S. N. and Mahsen, I. F., 2013. Reliance of the Environmental Management System for Evaluating and Rehabilitation the Iraqi Cement Factories (Iraqi Cement State Co.-Case Study). Diyala Journal of Engineering Sciences, 6(2), 16-46. (In Arabic).

Newman, J. and Choo, B.S. (2003). Advanced Concrete Technology; Constituent Materials. 1st edition, Butterworth Heinemann, Elsevier, UK, 288P.

Peray, K. E., 1986. The Rotary Cement Kiln. $2^{\text {nd }}$ edition, Edward Arnold Pty. Ltd. Victoria, Australia, 389P.

Rao, D. S., Vijayakumar, T. V., Prabhakar, S., \& Raju, G. B., 2011. Geochemical assessment of a siliceous limestone sample for cement making. Chinese Journal of Geochemistry, 30(1), 33-39.

Schafer, H. U., 1987. Assessment of Raw Materials for the Cement Industry. Reprinted from the Journal World Cement. Cement and Concrete Association, London, 7, 273-283.

Taylor, H. F. W., 1997. Cement Chemistry. $2^{\text {nd }}$ edition, Thomas Telford, London, UK, $459 \mathrm{P}$.

Yacoub, S.Y., Othman, A.A. and Kadim, T.H., 2012. Geomorphology of the Low Folded Zone. Iraqi Bull. Geol. Min., Special Issue, No.5, p. 7 - 37, In: Al-Obaidi, M.R. and Al-Shwaily, A.K., 2019. Paleostress Analysis Of Neogene Rocks In Zurbatiyah Area, E Iraq. Iraqi Bulletin Of Geology And Mining, 15(1), Pp.43-57.

Yezdeen, M. E., 1990. Assessment of Some Tertiary Rocks in Wadi Khan-Sinjar Area for the Production of Ordinary Portland Cement. Unpub. Msc. Thesis, College of Science, Mosul University, 197pp. (In Arabic). 